\title{
The Relationship Between Mediterranean Diet Adherence and Mindful Eating Among Individuals With High Education Level
}

\author{
Halide Yıldırım ${ }^{1}$, İrem Kaya Cebioğlu² (iD
}

${ }^{1}$ Istinye University, Department of Gastronomy and Culinary Arts, Istanbul, Turkey

${ }^{2}$ Yeditepe University, Faculty of Health Sciences, Department of Nutrition and Dietetics, Istanbul, Turkey

Halide YILDIRIM

İrem KAYA CEBIOĞLU

Correspondence: Irem Kaya Cebioğlu Yeditepe University, Faculty of Health Sciences, Department of Nutrition and Dietetics, istanbul, Turkey

Phone: +905354776833

E-mail: irem.cebioglu@yeditepe.edu.tr

\section{ABSTRACT}

Objectives: The aim of this study was to evaluate the relationship between the adherence to the Mediterranean diet and mindful eating of individuals with a high level of education.

Study design: This study conducted between November 2019 and March 2020 with 188 academicians participation. General information form, Mediterranean diet adherence scale (MEDAS) and mindful eating scale (MEQ-30) were used in the data collection. The data were collected via face-to-face interview method by the researcher.

Results: The mean age of the participants was $33.95 \pm 11.97$ years (range: $22-65$ years). According to the findings, majority of the participants (56.4\%) showed low adherence to the Mediterranean diet and $73.9 \%$ of them had higher mindful eating. Besides, although the difference were not significant, participants with high adherence to the Mediterranean diet had higher MEQ-30 scores and higher BMI ( $p>0.05$ ). The MEDAS score has positively correlated with the dimensions of the MEQ. As the disinhibition, the emotional eating, the control of eating, the mindfulness and the interference increased of the individual, the adherence to the Mediterranean diet increased simultaneously $(p<0.05)$.

Conclusion: Higher education level may be a predictive factor of mindful eating in company with compliance to the Mediterranean diet. These two eating attitudes may have beneficial effects on BMI and eating patterns of an individual which would cause weight loss and better health status.

Keywords: Mediterranean Diet, Mindfulness, Eating behavior

\section{Yüksek Eğitim Seviyesine Sahip Bireylerde Yeme Farkındalığı ile Akdeniz Diyetine Uyum Arasındaki Ilişki}

ÖZET

Amaç: Çalışma yüksek eğitim düzeyine sahip bireylerin akdeniz diyetine bağlıı̆ı ve yeme farkındalığı ile ilişkisini değerlendirmek amacıyla yapıımıştır.

Çalışma Planı: Çalışma Kasım 2019-Mart 2020 tarihleri arasında 188 akademisyen katılımılla gerçekleştirilmiştir. Veri toplama formunda genel bilgiler, Akdeniz diyetine bağılık ölçeği (MEDAS) ve yeme farkındalığı ölçeği (YFÖ-30) kullanılmıştır. Veriler araştırmacı tarafından yüz yüze görüşme yöntemi ile toplanmıştır.

Bulgular: Katılımcıların yaş ortalaması 33,95 $\pm 11,97^{\prime}$ dir (22-65 yaş). Bulgulara göre katılımcıların büyük bir çoğunluğu (\%56.4) Akdeniz diyetine düşük bağlıık gösteriyordu ve \%73,9'u daha yüksek yeme farkındalı̆ı̆ skoruna sahipti. Ayrıca fark istatistiksel anlamlı olmasa da, Akdeniz diyetine bağlılı̆ı yüksek olan bireyler daha yüksek YFÖ-30 skoru ve daha yüksek BKI'ne sahipti ( $p>0.05$ ). Bireylerin MEDAS skorunun YFÖ'nün alt boyutları ile pozitif korelasyonu vardı. Bireylerde disinhibisyon, duygusal beslenme, yeme kontrolü, farkındalık ve interferans arttıkça Akdeniz diyetine uyum da artıyordu $(\mathrm{p}<0.05)$.

Sonuç: Yüksek eğitim düzeyinin yeme farkındalığı ile birlikte Akdeniz diyetine uyumun bir öncü faktörü olabileceği oldukça açıktır. Bu iki yeme tutumu bireyin BKi ve yeme alışkanlıklarını olumlu etkileyerek sonuçta kilo kaybı ve daha iyi bir sağlık düzeyi sağlamada etkili olabilir.

Anahtar Kelimeler: Akdeniz Diyeti, Farkındalık, Yeme Davranışı $\begin{array}{ll}\text { Received } & : 22 \text { April } 2021 \\ \text { Accepted } & : 16 \text { May } 2021\end{array}$ 
$\mathbf{T}$ he Mediterranean diet model which is not only a diet but also a lifestyle, handles food in all aspects, has come to the fore as the healthiest and most sustainable diet recently. The health effects of the Mediterranean diet first emerged and defined for the first time in the late 1950s with a seven-country study by Angel Keys in which the relationship between heart diseases and diet was examined (1). In a conference held in Italy in 2009, it was considered as a sustainable diet due to its environmental, nutritional, economic and sociocultural dimension (2). It is a kind of diet that recommends consumption of high amounts of fruits, vegetables, legumes, fish and seafood, olive oil as the major oil source, moderate consumption of milk and wine, and low red meat consumption (3). People who consciously follow a more health-oriented diet are considered having higher cultural, social and economic awareness (4).

Mindfulness practices, which date back to ancient times, are used in many areas for different purposes nowadays (5). When the mindfulness level of the individual reaches a level that will affect the attitudes, mindful eating behaviors manifest itself, which focus on how and why the eating behavior occurs rather than what is eaten $(6,7)$. In other words, mindful eating is a way to focus on the food to be consumed without being affected by environmental factors and prejudices, being aware of the effects of emotions and thoughts by internalizing the concepts of physical hunger-satiety $(6,8)$.

The attitudes of individuals towards health are associated with food choices and shaping their eating patterns. It is seen that those who make health-oriented food preferences tend to follow a more balanced diet instead of junk food, energy-dense foods and large portions. There are many factors that affect consumers' food choices including genetic, biological, socioeconomic, environmental and psychological factors as well as cultural habits (9). Particularly socioeconomic factors (i.e. education and income) play a major role in a sustainable and healthy diet approach as more educated people tend to have a more balanced and healthy eating pattern due to higher levels of mindfulness and knowledge about foods (10). Knowing the role of the food in preventing chronic diseases brings along a healthier eating pattern and pro-environmental attitude. For instance, income and education level have a significant positive effect on adherence to the plant-based diet and sustainable Mediterranean diet $(10,11)$. Contrary, a decrease in education and income levels has a negative impact on food choices. Individuals with a low level of education have limited knowledge and lower awareness of food related issues and have also been reported to have difficulty following food recommendations $(10,12)$.

Although there are many studies investigated the relationship between the education level of individuals and adherence to the Mediterranean diet, the effects of the levels of mindfulness did not examine before. Yet in this study it was aimed to evaluate the relationship between the adherence to the Mediterranean diet and mindful eating among high educated participants.

\section{MATERIAL AND METHODS}

\section{Study participants/sample}

The research was conducted between November 2019-March 2020 with 188 academicians working at Yeditepe University. Those without chronic disease and completed the informed consent form were included. While sample size calculated as 302 with $95 \%$ confidence interval, the study was terminated with 188 people by reaching $62 \%$ of the desired sample because formal education was interrupted due to COVID-19.

\section{Procedure of investigation}

The data collected by the researcher through face-to-face interviews. Participants' socioeconomic characteristics (age, gender, marital status, educational status, and smoking), anthropometric characteristics (self-reported weight and height), physical activity status were questioned. The physical activity level of the individuals was determined by questioning the level of adaptation of participants to 150 minutes of moderate-intensity activity per week recommended by the World Health Organization (WHO) (13). BMI was calculated by dividing the weight in kilograms to height in meters $\left(\mathrm{kg} / \mathrm{m}^{2}\right)$ and classified according to WHO criteria (14). One of the two validated scales was used in this study was the Mediterranean Diet Adherence Scale which was developed by Martínez-González MÁ, Corella D, Salas-salvadó J, et al. in 2012 (15) and validated in Turkish by Pehlivanoğlu, Balcıoğlu and Ünlüoğlu (16). A total score of $\geq 7$ indicates an acceptable adherence, whereas a score of $\geq 9$ indicates high adherence to the Mediterranean diet (16). Secondly, the mindful eating questionnaire which was developed by Framson C, Kristal AR, Schenk JM, et al. in 2009 (17) and validated in Turkish were obtained by Köse, Tayfur, Birincioğlu et al. (6) was used. In Turkish version, a new scale consisting of 30 questions was created and divided into 7 sub-factors. The higher score indicates higher level of mindful eating $(6,18)$. 


\section{Statistical analysis}

Statistical Package for the Social Sciences software (SPSS) 21 program was used to analyze the data. Continuous variables were represented with mean $(\dot{X})$, standard deviation (SD), minimum-maximum (min-max) and qualitative variables with frequency (n) and percentages (\%). The normality assumption was examined by KolmogorovSmirnov test. Chi-square test was used to describe the relationship between two qualitative variables and the Mann-Whitney Test was used to determine whether the distributions of two independent variables were statistically significant. Chronbach's alpha was calculated to reveal the relationship between variables. The confidence interval for all analyzes were $95 \%$ and the results were considered statistically significant for $p<0.05$.

\section{Results}

A total of 188 academicians with a mean age of $33.95 \pm$ 11.97 years (min: 22 yrs, max: 65 yrs), comprised 125 women (66.5\%) and 63 men (33.5\%). As shown in Table 1, all participants were of high education level. Considering the MEDAS scores, while a majority of women showed an acceptable level of adherence, men showed higher adherence than women, but the difference was insignificant $(p>0.05)$. Women displayed insignificantly higher awareness about mindfulness than men ( $p>0.05)$. According to the classification of $\mathrm{BMI}$, overweight and obesity rates were significantly higher among men participants $(p<0.001)$.

\begin{tabular}{|c|c|c|c|c|c|c|c|c|}
\hline & & \multicolumn{2}{|c|}{ Overall } & \multicolumn{2}{|c|}{ Women } & \multicolumn{2}{|c|}{ Men } & \\
\hline & & $\mathrm{n}$ & $\%$ & $\mathrm{n}$ & $\%$ & $n$ & $\%$ & \\
\hline \multirow[t]{2}{*}{ Education status } & Master Degree & 97 & 51.6 & 65 & 52 & 32 & 50.8 & \\
\hline & PhD. & 91 & 48.4 & 60 & 48 & 31 & 49.2 & \\
\hline \multirow[t]{2}{*}{ Marital Status } & Married & 64 & 34 & 41 & 32.8 & 23 & 36.5 & \\
\hline & Single & 124 & 66 & 84 & 67.2 & 40 & 63.5 & \\
\hline \multirow[t]{2}{*}{ Physical Activity } & $<150 \mathrm{~min} /$ week & 133 & 70.7 & 97 & 77.6 & 36 & 57.1 & \\
\hline & $\geq 150 \mathrm{~min} /$ week & 55 & 29.3 & 28 & 22.4 & 27 & 42.9 & \\
\hline \multirow[t]{2}{*}{ Smoking } & Yes & 65 & 34.6 & 43 & 34.4 & 22 & 34.9 & \\
\hline & No & 123 & 65.4 & 82 & 65.5 & 41 & 65.1 & \\
\hline \multirow[t]{2}{*}{ Eating Status } & Alone & 54 & 28.7 & 34 & 27.2 & 20 & 31.7 & \\
\hline & Family/friends & 134 & 71.3 & 91 & 72.8 & 43 & 68.3 & \\
\hline \multirow{2}{*}{$\begin{array}{l}\text { Following a diet program } \\
\text { before }\end{array}$} & Yes & 109 & 58 & 52 & 41.6 & 27 & 42.9 & \\
\hline & No & 79 & 42 & 73 & 58.4 & 36 & 57.1 & \\
\hline & & & & & & & & $\begin{array}{l}\text { Significance } \\
\mathrm{p}^{*}\end{array}$ \\
\hline \multirow{3}{*}{$\begin{array}{l}\text { Adherence to Mediterranean } \\
\text { Diet Score }\end{array}$} & Low & 106 & 56.4 & 70 & 56 & 36 & 57.1 & \multirow[t]{3}{*}{0.158} \\
\hline & Acceptable & 57 & 30.3 & 42 & 33.6 & 15 & 23.8 & \\
\hline & High & 25 & 13.3 & 13 & 10.4 & 12 & 19 & \\
\hline \multirow[t]{2}{*}{ Awareness of mindful eating } & Yes & 96 & 51.1 & 68 & 54.4 & 28 & 44.4 & \multirow[t]{2}{*}{0.197} \\
\hline & No & 92 & 48.9 & 57 & 45.6 & 35 & 55.6 & \\
\hline \multirow[t]{4}{*}{ BMI } & Underweight & 18 & 9.6 & 16 & 12.8 & 2 & 3.2 & \multirow[t]{4}{*}{$0.000^{\mathrm{a}}$} \\
\hline & Normal & 115 & 61.2 & 92 & 73.6 & 23 & 36.5 & \\
\hline & Overweight & 41 & 21.8 & 14 & 11.2 & 27 & 42.9 & \\
\hline & Obese & 14 & 7.4 & 3 & 2.4 & 11 & 17.5 & \\
\hline
\end{tabular}


Table 2. BMI and MEQ-30 values regarding adherence to the Mediterranean diet

\begin{tabular}{|c|c|c|c|c|c|c|c|}
\hline & \multicolumn{2}{|c|}{ Low Adherence } & \multicolumn{2}{|c|}{ Acceptable Adherence } & \multicolumn{2}{|c|}{ High Adherence } & \multirow{2}{*}{$\begin{array}{l}\text { Sig. } \\
\mathrm{p}^{*}\end{array}$} \\
\hline & $\dot{\mathrm{X}} \pm \mathrm{SD}$ & Min.-Max. & $\dot{\mathrm{X}} \pm \mathrm{SD}$ & Min.-Max. & $\dot{\mathrm{X}} \pm \mathrm{SD}$ & Min.-Max. & \\
\hline BMI & $23.45 \pm 3.73$ & $17.68-33$ & $22.70 \pm 3.52$ & $17-31.50$ & $24.02 \pm 4.30$ & $17.92-33$ & 0.398 \\
\hline MEQ-30 & $3.27 \pm 0.53$ & $2.40-5$ & $3.29 \pm 0.54$ & $1.80-4.20$ & $3.44 \pm 0.59$ & $2.20-5$ & 0.422 \\
\hline
\end{tabular}

\begin{tabular}{|c|c|c|c|c|c|c|c|c|c|c|c|}
\hline & & Age & BMI & MEQ-30 & Disinhibition & $\begin{array}{l}\text { Emotional } \\
\text { Eating }\end{array}$ & \begin{tabular}{|l|} 
Eating \\
Control
\end{tabular} & Focusing & $\begin{array}{l}\text { Eating } \\
\text { Discipline }\end{array}$ & Mindfulness & Interference \\
\hline \multirow{2}{*}{ 容 } & $r$ & 0.224 & 0.11 & 0.125 & 0.312 & 0.241 & 0.202 & -0.0708 & 0.092 & 0.320 & 0.180 \\
\hline & $p$ & $0.002^{b}$ & 0.885 & 0.087 & $0.000^{a}$ & $0.001^{a}$ & $0.006^{b}$ & 0.285 & 0.207 & $0.000^{\mathrm{a}}$ & $0.013^{c}$ \\
\hline
\end{tabular}

At Table 2 shows the BMI and MEQ- 30 values of the participants according to their adherence to the Mediterranean diet. Participants with high adherence to the Mediterranean diet (score $\geq 9$ ) unexpectedly found to have higher BMI values however, this difference was statistically insignificant ( $p>0.05$ ). Besides, the MEQ30 scores of those who showed high adherence to the Mediterranean diet were found to be higher, while these results were not significant $(p>0.05)$.

Table 3 shows the MEQ-30 and MEDAS scores according to the BMI classification of the participants. Although no statistical significance was observed $(p=0.082)$, the MEQ30 scores of overweight and individuals with obesity were found to be lower $(3.17 \pm 0.57$ and $3.15 \pm 0.50$. respectively), compared to normal and underweight individuals (3.33 \pm 0.52 and $3.50 \pm 0.59$, respectively).

When MEDAS scores were examined according to the BMI classification, while the highest mean score was observed in underweight $(6.50 \pm 1.79)$ and overweight $(6.46 \pm 2.12)$ individuals, individuals with obesity displayed lowest adherence with a mean of $6.21 \pm 2.77$. There was no statistically significant difference between the MEDAS and BMI classification ( $p>0.05)$.

The adherence to the Mediterranean diet of individuals were not correlated neither BMI nor mindfulness $(p>0.05)$, displayed in Table 3. However, individuals found to be more compliant with the Mediterranean diet as they get older $(p<0.05)$. Besides, the MEDAS score was positively correlated with the 5 dimensions of the MEQ. As the subscales of disinhibition, the emotional eating, the control of eating, the mindfulness and the interference levels increase of an individual, the adherence with the Mediterranean diet increases simultaneously $(p<0.05)$.

\section{Discussion}

High education accompanied by socioeconomic status are major factors determining the eating habits of individuals, as those with low socioeconomic level tend to consume less healthy foods $(19,20)$. Individuals with a high level of education know the role of foods on diseases and follow dietary recommendations more easily (19), and reported to be highly adhered to Mediterranean diet (21). Another study also reported that those had lowest education level tend to consume higher amount of cereals and pulses, but lower amounts of vegetables, olive oils, milk and milk products (22). That is why it was important to select individuals with a high level of education as the target population for the study.

Even though this study did not aim to determine the contribution of demographic factors, we observed similar tendency with the literature in terms of the age and MEDAS score $(21,23,24)$, as older age reported to be a predictive factor on adherence (25), however a study reported no association (11). Regarding of sex, although there was no significant difference, men found to be displayed higher adherence than women in accordance with the literature findings $(11,22,23)$. Besides, there are contrary results which indicated women more compliant with the Mediterranean diet (11). 
Although The Mediterranean diet is associated with a reduction in risk of several diseases and conditions just as the BMI, this study found that there was no relationship between these two parameters in line with the literature (26), and those with higher compliance had higher BMI, similar to another study (27). In a cross-sectional study, which included only women, a decrease in the prevalence of overweight and obesity was observed as adherence to the Mediterranean diet increased (21). Different results between studies may be due to the differences in population groups and the self-reported height-weight measurements of the participants. Moreover, physical activity level also reported as an associated determinant with the moderate or high adherence to the Mediterranean diet (21). At the same time, failure to take food consumption record of individuals may have caused the MEDAS scale to be incorrectly filled. Apart from adherence to the Mediterranean diet, similar to our findings, a negative relationship was indicated between BMI and mindful eating score by a study (5) and it was indicated that mindful eating may be a possible effective approach to lower the $\operatorname{BMI}(5,28,29)$. The concepts of mindful eating and Mediterranean diet model coincide with each other, as both refer to eating behavior should be consciously to satisfy body and psychological requirements concomitantly (28). Moreover, in accordance with Ayyıldız Atak (30) study, we observed the MEDAS score of the individuals were significantly and positively associated with disinhibition, emotional eating, eating control, mindfulness, interference. This study hypothesized that those with higher education level would have higher mindful eating attitudes, and concomitantly would be more compliant with the Mediterranean diet. Even though we could not determine the exact significant association, it would not be wrong to deduce that those with higher MEQ scores tend to show higher adherence to the Mediterranean diet. Besides this study results reveal a positive relationship between MEDAS score and sub-factors of MEQ including disinhibition, emotional eating, eating control, mindfulness and interference.

\section{Conclusion}

This study aimed to determine the possible association between adherence to the Mediterranean diet and mindful eating practices among high educated adult population, in this respect it presents a new perspective to the literature. It is obvious that higher education level may be a predictive factor of mindful eating in company with compliance to the Mediterranean diet. As mindful eating practices of an individual increase, the tendency to comply with the Mediterranean diet would increase simultaneously. These two eating attitudes may have beneficial effects on BMI and eating patterns of an individual which would cause weight loss and better health status. As a conclusion, it is possible to gain healthier eating habits by increasing the education level of individuals. It is recommended for future studies to evaluate the change in adherence to the Mediterranean diet after education sessions in order to increase awareness of mindful eating of individuals.

\section{Declarations}

Funding: This research did not receive any specific grant from funding agencies in the public, commercial, or notfor-profit sectors.

Conflict of Interest/competing interest: The authors declare that they have no conflict of interests.

Availability of Data And Materials: 'Not applicable'.

Ethics Approval: This study was performed with the ethical approval of Yeditepe University Clinical Researches Ethics Committee, with date 28.01.2021 and number 2021/01-44.

Authors' Contributions: First author participated in the conception and design of the study, collection and acquisition of the data, performed statistical analysis also she drafted and revised the manuscript. Second author performed as the coordinator of the study and also performed statistical analysis, contributed to interpretation of the results, participated in the acquisition of data and revised the manuscript. All authors accept full responsibility for all aspects of the research.

\section{References}

1. Keys A, Menotti A, Karvonen MJ, et al. The diet and 15-year death rate in the Seven Countries Study The Diet And 15-Year Death Rate In The Seven Countries Study. 1986;124:903-15. DOI:10.1093/ oxfordjournals.aje.a114480

2. Saulle R, La Torre G. The Mediterranean Diet, recognized by UNESCO as a cultural heritage of humanity. Ital J Public Health. 2010;7:414-5. DOI:10.2427/5700

3. Stefler D, Malyutina S, Kubinova R, et al. Mediterranean diet score and total and cardiovascular mortality in Eastern Europe: the HAPIEE study. Eur J Nutr. 2017;56:421-9. DOI:10.1007/s00394-015-1092-x

4. Burlingame B, Dernini S. Sustainable diets: the Mediterranean diet as an example. Public Health Nutr. 2011;14:2285-7. DOI:10.1017/ S1368980011002527

5. Moor KR, Scott AJ, Mclntosh WD. Mindful Eating and Its Relationship to Body Mass Index and Physical Activity Among University Students. Mindfulness (NY). 2013;4:269-74. DOI:10.1007/s12671-012-0124-3 
6. Köse G, Tayfur M, Birincioğlu İ, et al. Yeme Farkındalığı Ölçeği ' ni Türkçeye Uyarlama Çalışması. Bilişsel Davranış̧̧ı Psikoterapi ve Araştırmalar Derg. 2016;3:125-34. DOI:10.5455/JCBPR.250644

7. Çolak H, Aktaç Ş. Ağırlık Yönetimine Yeni Bir Yaklaşım: Yeme Farkındalığı A New Approach to Weight Management: Mindful Eating. Adnan Menderes Üniversitesi Sağlık Bilim Fakültesi Dergisi. 2019;3:212-22. Retrieved from https://dergipark.org.tr/tr/pub/ amusbfd/issue/49133/549387

8. Özkan N, Bilici S. Yeme DavranışındaYeni Yaklaşimlar:Sezgisel Yeme Ve Yeme Farkindaliği. Gazi Sağlık Bilim Derg [Internet]. 2018;3:1624. Retrieved from: https://dergipark.org.tr/tr/pub/gsbdergi/ issue/37812/432979

9. Cavaliere A, De Marchi E, Banterle A. Healthy-unhealthy weight and time preference. Is there an association? An analysis through a consumer survey. Appetite [Internet]. 2014;83:135-43. DOI:10.1016/j.appet.2014.08.011

10. Cavaliere A, De Marchi E, Banterle A. Exploring the adherence to the mediterranean diet and its relationship with individual lifestyle: The role of healthy behaviors, pro-environmental behaviors, income, and education. Nutrients. 2018;10. DOI:10.3390/nu10020141

11. Mohtadi K, Msaad R, Benalioua N, et al. Sociodemographic and Lifestyle Factors Associated with Adherence to Mediterranean Diet in Representative Adult Population in Casablanca City, Morocco: A Cross-Sectional Study. J Nutr Metab. 2020 Mar:2020:3105271. DOI:10.1155/2020/3105271

12. Darmon N, Drewnowski A. Does social class predict diet quality ? Am J Clin Nutr. 2008;87: 1107-1117. DOI:10.1093/ajcn/87.5.1107.

13. WHO. Physical activity. World Health Organization. 2020. [Internet] Retrieved from: https://www.who.int/news-room/fact-sheets/ detail/physical-activity Accessed April 15, 2021.

14. WHO. WHO Europe Nutrition - Body mass index - BMI [Internet]. World Health Organization. 2018. Retrieved from: https://www.euro. who.int/en/health-topics/disease-prevention/nutrition/a-healthylifestyle/body-mass-index-bmi Acessed April 15, 2021.

15. Martínez-González MÁ, Corella D, Salas-salvadó J, et al. Cohort profile: Design and methods of the PREDIMED study. Int J Epidemiol. 2012;41:377-385. DOI:10.1093/ije/dyq250

16. Özkan Pehlivanoğlu EF, Balcıoğlu H, Ünlüoğlu í. Akdeniz Diyeti Bağlılık Ölçeği'nin Türkçe'ye Uyarlanması Geçerlilik ve Güvenilirliği. OSMANGAZI J Med. 2019.DOI:10.20515/otd.504188

17. Framson C, Kristal AR, Schenk JM, et al. Development and validation of the mindful eating questionnaire. J Am Diet Assoc. 2009;109:14391444. DOI:10.1016/j.jada.2009.05.006

18. Köse G, Çıplak ME. Does mindful eating have a relationship with gender,body mass index and health promoting lifestyle? Prog Nutr. 2020;22:528-535. doi:10.23751/pn.v22i2.9268

19. Whichelow MJ, Prevost AT. Dietary patterns and their associations with demographic, lifestyle and health variables in a random sample of British adults. Br J Nutr. 1996;76:17-30. DOI:10.1079/bjn19960006

20. Affret A, Severi G, Dow C, et al. Socio-economic factors associated with a healthy diet: Results from the E3N study. Public Health Nutr. 2017:20:1574-83. DOI:10.1017/S1368980017000222

21. Maugeri A, Barchitta $M$, Fiore $V$, et al. Determinants of adherence to the mediterranean diet: Findings from a cross-sectional study in women from Southern Italy. Int J Environ Res Public Health. 2019;16:1-14. DOI:10.3390/ijerph16162963

22. González CA, Argilaga S, Agudo A, et al. Diferencias sociodemográficas en la adhesión al patrón de dieta mediterránea en poblaciones de España. Gac Sanit. 2002;16:214-21. DOI:10.1016/ S0213-9111(02)71664-6
23. Filippidis FT, Tzavara C, Dimitrakaki C, et al. Compliance with a healthy lifestyle in a representative sample of the Greek population: Preliminary results of the Hellas Health I study. Public Health [Internet]. 2011;125:436-41. Available from: DOI:10.1016/j. puhe.2011.03.009

24. Kyriacou A, Evans JMM, Economides $N$, et al. Adherence to the Mediterranean diet by the Greek and Cypriot population: A systematic review. Eur J Public Health. 2015;25:1012-8. DOI:10.1093/ eurpub/ckv124

25. Arcila-Agudelo AM, Ferrer-Svoboda $C$, Torres-Fernàndez $T$, et al. Determinants of adherence to healthy eating patterns in a population of children and adolescents: Evidence on the mediterranean diet in the city of mataró (catalonia, spain). Nutrients. 2019;11:1-13. DOI:10.3390/nu11040854

26. Rossi $M$, Negri $E$, Bosetti $C$, et al. Mediterranean diet in relation to body mass index and waist-to-hip ratio. Public Health Nutr. 2008;11:214-7. DOI:10.1017/S1368980007000833

27. Henríquez Sánchez P, Ruano C, De Irala J, et al. Adherence to the Mediterranean diet and quality of life in the SUN Project. Eur J Clin Nutr. 2012;66:360-8. DOI:10.1038/ejen.2011.146

28. Czepczor-Bernat K, Brytek-Matera A, Gramaglia C, et al.The moderating effects of mindful eating on the relationship between emotional functioning and eating styles in overweight and obese women. Eat Weight Disord [Internet]. 2020;25:841-9. Available from: https://doi.org/10.1007/s40519-019-00740-6

29. Daly P, Pace T, Berg J, et al. A mindful eating intervention: A theoryguided randomized anti-obesity feasibility study with adolescent Latino females. Complement Ther Med [Internet]. 2016;28:22-8. Available from: DOI:10.1016/j.ctim.2016.07.006

30. Ayyıldız Atak ND. Akdeniz Diyetine Bağlılıkla Yeme Farkındalığı ve Sezgisel Yeme Farkındalığı Arasındaki İlișkinin Değerlenidirilmesi. Master Dissertation Acıbadem Mehmet Ali Aydınlar University 2020. 